\title{
Persepsi Pasien Tentang Aspek Hukum Perikatan Upaya (Inspanning Verbintenis) Dalam Transaksi Terapeutik Antara Dokter Dengan Pasien Di RSUD Kota Salatiga
}

\author{
Bonifasius Nadya Aribowo, B. Resti Nurhayati dan Sofyan Dahlan \\ boni_nadya@yahoo.com \\ Magister Hukum Kesehatan \\ Universitas Katolik Soegijapranata Semarang
}

\begin{abstract}
ABSTRAK
Konstruksi hukum dalam transaksi terapetik sudah terlembaga dalam ketentuan perundang-undangan nasional, namun persepsi pasien tentang aspek hukum perikatan upaya dalam transaksi terapeutik masih demikian beragam, tidak utuh, bahkan sebagian kabur. Penelitian ini bertujuan untuk melihat bagaimana persepsi pasien tentang aspek hukum perikatan upaya (inspanning verbintenis) dalam transaksi terapeutik antara dokter dengan pasien.

Partisipan dalam penelitian ini adalah 15 orang pasien di RSUD Salatiga. Tehnik pengambilan sampel dengan menggunakan metode cluster random sampling dengan populasi : pasien yang sedang menjalani rawat inap berdasarkan perikatan atas kontrak di RSUD Kota Salatiga dalam jangka waktu satu bulan sejak pasien masuk dirawat inap di RSUD Kota Salatiga, Tehnik pengambilan data dengan studi lapangan lewat observasi dan wawancara yang mendalam (deep interview) secara terarah (directive interview), dengan analisa data secara kualitatif yang diuraikan secara deskriptif-naratif maupun menggunakan table maupun diagram secara statistik.

Hasil yang didapatkan memperlihatkan bahwa 73,3 \% responden memiliki persepsi tentang adanya hubungan hukum dalam transaksi terapetik. Persepsi responden tentang aspek hukum turunan dalam transaksi terapetik meliputi berlakunya hubungan kontraktual dalam transaksi terapeutik, sifat perikatan dalam transaksi terapeutik; serta hak dan kewajiban dokter dan pasien dalam hubungan kontraktual dalam transaksi terapeutik memiliki korelasi dengan latar belakang tingkat pendidikan responden.
\end{abstract}

Kata kunci : persepsi pasien, perikatan upaya, transaksi terapetik 


\section{A. Latar Belakang}

Motivasi seorang pasien mendatangi seorang dokter tiada lain adalah kesembuhan, atau setidak-tidaknya berupa peningkatan kualitas kondisi kesehatan sang pasien. Padahal praktik kedokteran dimaknai sebagai suatu rangkaian kegiatan yang dilakukan oleh dokter terhadap pasien dalam melaksanakan upaya kesehatan.

Tidak jarang, pasien merasa kecewa dengan upaya kesehatan yang diterimanya, manakala upaya kesehatan yang dijalaninya dinilai tidak membuahkan hasil sebagaimana yang diharapkan, yakni kesembuhan.

Pasien mengajukan komplain atas pelayanan kesehatan yang dianggap tidak memuaskan, bahkan tidak membawa hasil sama sekali dan atau lebih jauh lagi manakala justru berujung pada kegagalan medis, meski pasien merasa telah mengikuti saran maupun petunjuk dokter, baik sejak dalam rangka penegakan diagnosa hingga treatment tindakan medis dari sang dokter dengan segala konsekwensinya.

Di sisi lain dokter dengan segenap kemampuannya berdasarkan disiplin ilmu kedokteran, kode etik serta standar profesi dan standard operasional prosedur pelayanan kesehatan telah menjalankan profesinya dengan sungguh-sungguh demi kesembuhan sang pasien. Per primum non nocere, sedapat mungkin jangan sampai menyakiti, berusaha menyembuhkan sebisanya penyakit pasien. Meski demikian, dengan kemajuan ilmu kedokteran dan tehnologi, dokter akan dapat lebih banyak mengatakan mengenai hasilnya, dokter tetap saja tidak diperkenankan menjanjikan hasil berupa kesembuhan atas derita keluhan sakit pasien'. Hanya sebagai pengecualian saja dokter dapat mengatakan hasilnya.

Guwandi dalam bukunya yang berjudul "Dokter, Pasien, dan Hukum" mengatakan bahwa, hubungan antara dokter dan pasien merupakan bagian dari wilayah hukum perdata yang memberi kebebasan bagi para pihak untuk membuat perjanjian. ${ }^{2}$ Namun, satu hal yang harus diingat bahwa perikatan terapeutik tidak bersifat "bebas" secara kontraktual, karena kandungan dari sifat perikatan terapeutik tunduk pada ketentuan hukum/normatif positif. Wujud prestasi maupun kontra prestasi dalam perikatan terapeutik telah ditentukan sedemikian rupa dalam standar normatif, etis maupun ilmu kedokteran.

Secara teoritis, perikatan yang timbul dari suatu perjanjian terbagi dalam dua model perikatan hukum, yakni perikatan hasil (resultaats verbintenis) dan perikatan berusaha (inspannings verbintenis). Suatu perikatan disebut perikatan hasil apabila debitur berkewajiban menghasilkan suatu akibat tertentu. Sedangkan suatu perikatan disebut perikatan upaya manakala debitur berkewajiban`melakukan suatu usaha (pemeliharaan, perawatan dan pengabdian) tertentu untuk mencapai suatu tujuan tertentu. ${ }^{3}$

Seorang dokter berkewajiban memberikan serangkaian langkah-langkah upaya kesehatan tertentu berdasarkan norma standar profesi yang merupakan pedoman dalam menjalankan profesi secara baik, yang sudah ditetapkan dalam standar pelayanan medis yang sah. Jaminan perlindungan hukum terhadap hak pasien dalam praktek penyelenggaraan jasa pelayanan kesehatan tidak berupa klausul-klausul janji kesembuhan pasien secara kontraktual sebagai out put riil prestasi kondisi kesehatan pasien, melainkan mendasarkan pada tiga instrumen standar pelayanan medis yang sah, yakni:

\footnotetext{
1 J. Guwandi, Dugaan Malpraktek Medik \& draft RPP : " Perjanjian Terapeutik antara Dokter dan Pasien, Jakarta, Fakultas Kedokteran Universitas Indonesia, 2006, hal. 1

2 J. Guwandi, 2003, Op cit, hal. 1

${ }^{3}$ Mahkamah Agung RI, 1992, Bunga Rampai tentang Medical Malpractice Jilid I, Uraian teoritis tentang Medical Malpractice, disertai Peraturan Perundang-undangan, hal 3-4
} 
a. Instrumen hukum yang diwujudkan dalam regulasi peraturan perundang-undangan yang terkait dengan praktik kedokteran;

b. Instrumen etik profesi kedokteran yang diwujudkan dalam kode etik kedokteran;

c. Instrumen disiplin ilmu kedokteran yang diwujudkan dalam standar profesi kedokteran dan standar operasional prosedur (SOP) pelayanan kesehatan. ${ }^{4}$

Dokter (debitur) sebagai penyedia dan penyelenggara jasa pelayanan kesehatan memiliki kewajiban untuk melakukan serangkaian upaya kesehatan kepada pasien dan patuh dan tunduk pada norma-norma hukum, etika dan standar profesi medis, yang salah satu diantaranya adalah memberi penghormatan dan perlindungan terhadap hak-hak pasien menurut Pasal 51 Undang Undang Nomor 29 tahun 2004 tentang Praktik Kedokteran (selanjutnya disingkat UUPK).

Sedangkan pasien (kreditur) memiliki kewajiban untuk memberikan informasi yang sejujur-jujurnya dan selengkap-lengkapnya bagi kepentingan diagnosis dan terapi, mematuhi semua nasihat dokter, mematuhi ketentuan yang berlaku di sarana pelayanan kesehatan serta memberikan imbalan yang layak sebagai kontra-prestasi dari jasa atas serangkaian upaya medis yang diperolehnya kepada pihak dokter sebagaimana dinyatakan Pasal 53 UUPK.

Demikianlah, sifat inspanning verbintenis dalam transaksi terapeutik antara dokter dengan pasien sedemikian rupa telah dikonstruksikan lewat regulasi normatif secara limitatif. Meski demikian, tidak jarang hubungan hukum antara dokter dengan pasien dalam transaksi terapeutik berakhir menjadi perselisihan dan persengketaan hukum. Salah satu hal yang melatar-belakangi munculnya complain yang menyebabkan terjadinya perselisihan hingga sengketa hukum dalam transaksi terapeutik adalah adanya kesalahan-pandangan (mispersepsi) dan atau keberbedaan pandangan menyangkut aspek hukum perikatan upaya (inspanning verbintenis) dalam transaksi terapeutik antara dokter dengan pasien.

Kesalahan-pandangan atau mispersepsi, baik dari pihak dokter maupun pasien terhadap aspek hukum perikatan upaya dalam transaksi terapeutik tersebut mengakibatkan logika yang keliru dalam mengasumsikan konsekwensi maupun implikasi lanjutan khususnya secara hukum atas suatu tindakan medis dalam transaksi terapeutik.

Manakala persepsi masyarakat umum khususnya masyarakat pasien terhadap konstruksi hukum berikut implikasi hukumnya dalam transaksi terapeutik sesuai dengan norma-norma hukum yang berlaku, maka hal tersebut akan berpengaruh pada sikap dan model respon komplainpasien terhadap pelayanan praktik kedokteran yang diterimanya, yang cenderung berwujud klarifikasi medis dan atau medical complain yang nota bene masih di wilayah disiplin ilmu kedokteran/medis. Namun demikian manakala medical complain tersebut berlanjut menjadi sengketa hukum maka dalil hukumnya adalah perbuatan melanggar hukum (PMH), bukan wanprestasi.

Sedangkan, manakala persepsi masyarakat umum, khususnya masyarakat pasien terhadap konstruksi hukum transaksi terapeutik tidak sesuai dengan konstruksi normanorma hukum yang berlaku, maka sikap maupun model respon komplain pasien yang muncul cenderung bersifat klaim pertanggung jawaban hukum dengan dalil wanprestasi atau ingkar janji atau cidera janji, dengan skema sebagai berikut :

${ }^{4}$ J. Guwandi, 2006, op. cit., hlm. 39 


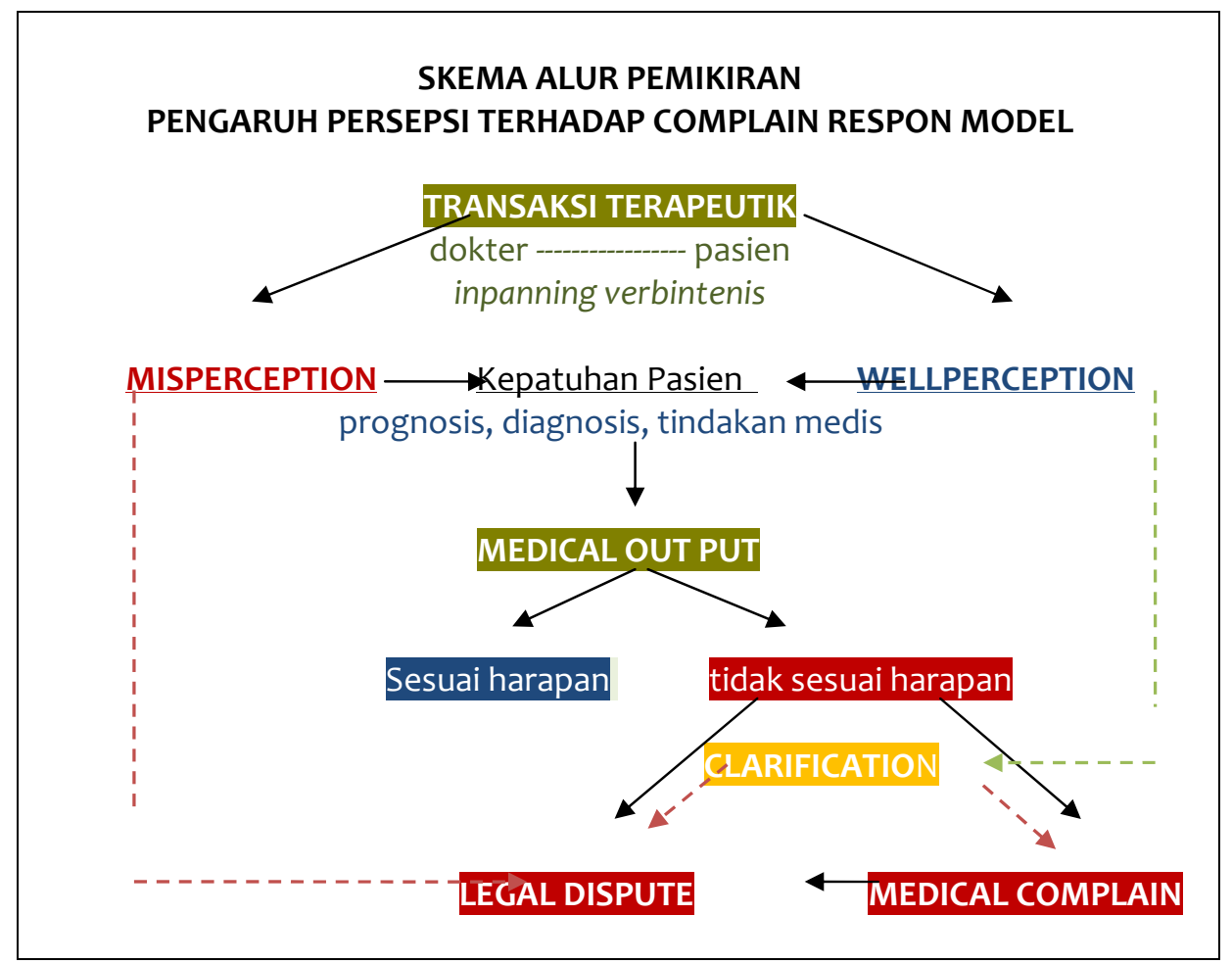

Berangkat dari uraian di atas maka penelitian ini hendak mencoba meneliti secara kualitatif bagaimana persepsi pasien terhadap aspek hukum perikatan upaya (inspanning verbintenis), dalam hubungan terapeutik antara dokter dengan pasien dalam penelitian yang diberi judul : "Persepsi Pasien tentang Aspek Hukum Perikatan Upaya (Inspanning Verbintenis) dalam Transaksi Terapeutik Dokter dengan Pasien di RSUD Kota Salatiga".

\section{B. Perumusan Masalah}

Berangkat dari latar-belakang di atas, penelitian ini secara deskriptif hendak melihat bagaimana persepsi pasien tentang aspek hukum perikatan upaya dalam hubungan terapeutik dokter dengan pasien dengan mengambil sampel penelitian secara random terhadap pasien yang sedang menjalani rawat inap di RSUD Kota Salatiga, dengan rumusan masalah sebagai berikut, yakni : Bagaimana persepsi pasien ditinjau aspek kognitif persepsi pasien tentang aspek hukum perikatan upaya (inspanning verbintenis) dalam transaksi terapeutik antara dokter dengan pasien di RSUD Kota Salatiga ?

\section{Metode Penelitian}

Penelitian tesis ini menggunakan metode pendekatan sosio legal (yuridis empiris), yang secara deskriptif mencoba ingin menggambarkan bagaimana persepsi pasien terhadap aspek hukum perikatan upaya (inspanning verbintenis) dalam transaksi terapeutik antara dokter dengan pasien yang sedang menjalani rawat inap di RSUD Kota Salatiga secara apa adanya.

Populasi penelitian ini adalah seluruh pasien RSUD Kota Salatiga yang sedang menjalani rawat inap di RSUD Kota Salatiga berdasarkan perikatan atas kontrak sejak pasien terdaftar sebagai pasien rawat inap di RSUD Kota Salatiga, terhitung sejak tanggal 01 Desember 2009 sampai dengan tanggal 31 Desember 2009, dengan klasifikasi pasien non poli gigi dan non peri natal di semua level kelas ruangan yang ditangani oleh dokter umum dan 
dokter spesialis yang merupakan dokter pegawai RSUD Kota Salatiga yang seluruhnya berjumlah 677 orang.

\section{Hasil Penelitian}

Berdasarkan hasil wawancara terhadap 15 responden pasien rawat inap di RSUD Kota Salatiga, yang kesemuanya adalah pasien dewasa atau bukan anak menurut peraturan perundang-undangan atau telah/pernah menikah, tidak terganggu kesadaran fisiknya, mampu berkomunikasi secara wajar, tidak mengalami kemunduran perkembangan (retardasi) mental dan tidak mengalami penyakit mental sehingga mampu membuat keputusan secara bebas sebagaimana dimaksud Pasal 1 Permenkes RI No.290/Menkes/Per/III/ 2008 tentang Persetujuan Tindakan Kedokteran, diperoleh stratifikasi pasien berdasarkan kategori latar belakang tingkat pendidikan, klas kamar rawat inap maupun jenis kelamin adalah sebagai berikut :

Tabel 1 : Latar Belakang Responden ditinjau dari Aspek Tingkat Pendidikan, Klas Kamar Rawat Inap dan Jenis Kelamin

\begin{tabular}{|c|c|c|c|c|c|c|c|}
\hline \multirow{2}{*}{$\begin{array}{c}\text { Stratifikasi Responden Berdasarkan } \\
\text { Kategori Tingkat Pendidikan }\end{array}$} & \multirow{2}{*}{ Jumlah } & \multicolumn{2}{|c|}{ Jenis kelamin } & \multicolumn{5}{|c|}{ Klas Kamar } \\
\cline { 4 - 10 } & & Pria & Wanita & VIP & I & II & III \\
\hline Tamat Pendidikan Dasar 9 Tahun & 8 & 5 & 3 & 1 & - & 1 & 6 \\
\hline Tamat Pendidikan SMA & 4 & 1 & 3 & 3 & - & - & 1 \\
\hline Tamat Pendidikan D3 s/d sarjana & 3 & 2 & 1 & 2 & 1 & - & - \\
\hline Total & 15 & 8 & 7 & 6 & 1 & 1 & 7 \\
\hline
\end{tabular}

Sumber: Data primer, wawancara responden di RSUD Kota Salatiga, 2009

Dari 15 responden, 11 responden (73,3\%) memiliki pandangan bahwa bahwa dalam transaksi terapeutik terkandung hubungan hukum, sedangkan empat responden $(26,7 \%)$ lainnya tidak mengetahui adanya hubungan hukum dalam transaksi terapeutik. Empat responden yang menjawab tidak mengetahui, dapat dipilahkan lagi menjadi dua kelompok, yakni dua orang responden (13,35\%) berpandangan bahwa tidak ada hubungan hukum dalam transaksi terapeutik antara dokter dengan pasien; serta dua responden sisanya (13,35\%) menyatakan tidak tahu.

Persepsi responden tentang hubungan hukum dalam transaksi terapeutik memiliki hubungan korelatif dengan latar belakang tingkat pendidikan responden. Semakin tinggi latar belakang pendidikan responden maka persepsi responden tentang ada tidaknya hubungan hukum dalam transaksi terapeutik juga semakin baik. 


\begin{tabular}{|c|c|c|c|c|}
\hline \multirow{2}{*}{\multicolumn{2}{|c|}{$\begin{array}{l}\text { Persepsi Pasien tentang Sejak Kapan Hubungan } \\
\text { Hukum dalam Transaksi Terapeutik Terjadi }\end{array}$}} & \multicolumn{2}{|c|}{ Responden } & \multirow{2}{*}{$\%$} \\
\hline & & jumlah & $\%$ & \\
\hline \multirow[b]{2}{*}{ Tahu } & sejak pendaftaran diri & 2 & 18,18 & \multirow[b]{2}{*}{27,27} \\
\hline & $\begin{array}{l}\text { sejak ada kesepakatan pasien dengan } \\
\text { dokter/RS }\end{array}$ & 1 & 09,09 & \\
\hline \multirow{5}{*}{ Tidak tahu } & sejak masuk RS & 3 & 27,27 & \multirow{5}{*}{72,72} \\
\hline & sejak masuk UGD & 2 & 18,18 & \\
\hline & sejak diperiksa & 1 & 09,09 & \\
\hline & $\begin{array}{l}\text { Sejak terjadi hal hal yang tidak } \\
\text { diinginkan }\end{array}$ & 1 & 09,09 & \\
\hline & tidak tahu & 1 & 09,09 & \\
\hline & Total & 11 & 100,00 & $100 \%$ \\
\hline
\end{tabular}

Sumber : Data primer, wawancara responden di RSUD Kota Salatiga, 2009

Berdasarkan latar belakang tingkat pendidikan responden memiliki korelasi dengan persepsi responden perihal aspek hukum dalam transaksi terapeutik, yakni :

1. Responden yang memiliki latar belakang tingkat pendidikan D3 s/d. S-1 ke atas memahami bahwa dalam transaksi terapeutik terdapat hubungan hukum yang sifat perikatan hukumnya perjanjian upaya, dan hubungan hukum dalam transaksi terapeutik dimulai sejak pasien mendaftarkan diri secara administratif ke RS (33,3\%).

Mengenai berakhirnya hubungan hukum dalam transaksi terapeutik, masing masing responden memiliki pandangan yang berbeda-beda, namun responden tidak memiliki pemahanan bahwa hubungan hukum dalam transaksi terapeutik dapat berakhir manakala pasien sembuh atau pasien sudah tidak lagi memerlukan penanganan dokter, pasien meninggal dunia, atau dokter telah selesai melaksanakan kewajibannya atau meninggal dunia.

Terkait dengan hak-hak serta kewajiban pasien dan dokter, dapat disimpulkan bahwa masing masing responden memiliki pandangan dan pendapat yang berbeda-beda. Persepsi bahwa dokter berhak atas imbalan jasa/honorarium dipahami secara mutlak $(100 \%)$ oleh responden. Namun mengenai hak-hak dokter lainnya, responden tidak mengetahuinya.

Sedangkan persepsi responden dari lima klausul kewajiban-kewajiban dokter sebagaimana telah diatur dalam UUPK, dua klausul kewajiban berhasil dieksplorasi dan secara penuh. Sedangkan tiga klausul kewajiban-kewajiban dokter yang lain belum dimengerti dan dipahami responden, yakni : klausul kewajiban untuk merujuk pasien ke dokter atau dokter gigi lain yang mempunyai keahlian atau kemampuan yang lebih baik apabila tidak mampu melakukan suatu pemeriksaan atau pengobatan; dan kewajiban untuk merahasiakan segala sesuatu yang diketahuinya tentang pasien.

2. Semua responden yang memiliki latar belakang pendidikan SMU memiliki pemahaman bahwa dalam transaksi terapeutik terdapat hubungan hukum (100\%) yang bersifat perikatan upaya/perjanjian berusaha (50\%) atau perikatan hasil (25\%) atau perikatan upaya maupun hasil/keduanya (25\%). 
Perihal sejak kapan hubungan hukum tersebut terjadi ada beberapa pendapat, yakni : sejak pasien mendaftarkan diri secara administratif (25\%) dan berakhirnya hubungan hukum dalam transaksi terapeutik responden memiliki pendapat yang berbeda-beda.

Terkait dengan hak-hak dan kewajiban pasien dan dokter responden tidak memiliki pemahaman yang merata, terstruktur dan menyeluruh perihal hak hak pasien. Namun terkait dengan hak-hak dokter, responden memahami hak dokter atas imbalan jasa/honorarium secara $100 \%$.

3. Responden yang memiliki latar belakang strata pendidikan setingkat pendidikan dasar ke bawah (SMP ke bawah) memilki pemahaman/pendapat tentang adanya hubungan hukum transaksi terapeutik terdapat hubungan hukum (50\%), dalam transaksi terapeutik tidak terdapat hubungan hukum (25\%) dan $25 \%$ responden menyatakan tidak tahu.

Perihal sejak kapan hubungan hukum dalam transaksi terapeutik terjadi responden memiliki pandangan yang berbeda beda.

Mengenai hak-hak dan kewajiban pasien dan dokter yang dipahami responden berdasarkan UUPK, responden tidak memilki pemahaman secara merata, terstruktur dan menyeluruh perihal kewajiban-kewajiban pasien. Namun semua kewajiban-kewajiban pasein sebagaimana telah diatur dalam Pasal 53 UUPK telah berhasil dieksplorasi dan dipahami oleh responden dengan prosentase sebagai berikut : kewajiban untuk memberikan informasi yang lengkap dan jujur tentang masalah kesehatannya sebanyak $12,5 \%$, kewajiban untuk mematuhi nasihat dan petunjuk dokter atau dokter gigi sebanyak $45 \%$, kewajiban untuk mematuhi ketentuan yang berlaku di sarana pelayanan kesehatan sebanyak $87,5 \%$ dan kewajiban untuk memberikan imbalan jasa atas pelayanan yang diterima sebanyak $87,5 \%$.

Mengenai hak-hak dokter, responden berpendapat sama yakni : hak memperoleh honorarium (100\%), hak untuk memperoleh perlindungan hukum sepanjang melaksanakan tugas sesuai dengan standar profesi dan standar prosedur operasional sebanyak 12,5\%, hak untuk memberikan pelayanan medis menurut standar profesi dan standar prosedur operasional tidak satupun responden yang memahami (0\%), hak untuk memperoleh informasi yang lengkap dan jujur dari pasien atau keluarganya sebanyak 37,5\%.

Terakhir menyangkut kewajiban dokter, responden tidak memiliki pemahaman secara merata, terstruktur dan menyeluruh perihal kewajiban-kewajiban dokter, namun dari 5 klausul kewajiban-kewajiban dokter sebagaimana telah diatur dalam Pasal 51 UUPK hanya dua klausul kewajiban yang telah berhasil dieksplorasi dan dipahami oleh responden meski tidak secara penuh.

Sedangkan masih ada 4 klausul kewajiban-kewajiban dokter yang lain belum dimengerti dan dipahami responden, yakni klausul: kewajiban untuk merujuk pasien ke dokter atau dokter gigi lain yang mempunyai keahlian atau kemampuan yang lebih baik apabila tidak mampu melakukan suatu pemeriksaan atau pengobatan, kewajiban untuk merahasiakan segala sesuatu yang diketahuinya tentang pasien, bahkan juga setelah pasien itu meninggal dunia, kewajiban untuk menambah ilmu pengetahuan dan mengikuti perkembangan ilmu kedokteran atau kedokteran gigi.

Berdasar paparan diatas, akhirnya perlu direkomendasikan saran-saran sebagai berikut : Diperlukan program-program sosialisasi hukum kesehatan bagi masyarakat untuk menumbuhkan pengetahuan, pemahaman serta kesadaran hukum masyarakat dalam bidang pelayanan kesehatan.

1. Mensikapi kondisi persepsi pasien terhadap aspek hukum dalam transaksi terapeutik yang masih rendah, maka penyelenggara jasa pelayanan kesehatan diharapkan membuat 
standar operasional prosedur pelayanan kesehatan yang berbasis hukum sebagai jaminan perlindungan hukum bagi pasien dan dokter.

2. Bagi pemerintah khususnya kementrian maupun dinas kesehatan membuat peraturan bagi penyelenggara jasa pelayanan kesehatan untuk menyediakan media-media edukasi hukum bagi pasien, keluarga maupun masyarakat umum tentang ketentuan-ketentuan hukum dalam praktik penyelenggaraan pelayanan kesehatan yang mudah diakses bagi pasien, keluarga maupun masyarakat umum.

\section{DAFTAR PUSTAKA}

Achadiat, CM. 2007. Dinamika Etika dan Hukum Kedokteran dalam Tantangan Zaman. Edisi I. Jakarta : Penerbit Buku Kedokteran EGC.

Chasawi, Adami, 2007, Malpraktik Kedokteran, Tinjauan Norma dan Doktrin Hukum, Edisi I, Malang : Bayumedia Publising.

Guwandi, J., 2003., 301 Tanya jawab : Informed Consent \& Inform Refusal, III, Jakarta, Balai Penerbit Fakultas Kedokteran Universitas Indonesia

---_--,Guwandi, J., 2003., Dokter, Pasien dan Hukum, I, Jakarta, Balai Penerbit Fakultas Kedokteran Universitas Indonesia

--------, 2004., Hukum Medik (Medical Law), Jakarta : Balai Penerbit Fakultas Kedokteran Universitas Indonesia

-------, 2005, Medical Eror dan Hukum Medis, I, Jakarta, Balai Penerbit Fakultas Kedokteran Universitas Indonesia

------, 2005, Rahasia Medis, I, Jakarta, Balai Penerbit Fakultas Kedokteran Universitas Indonesia

---------, 2006, Dugaan Malpraktek, I, Jakarta, Balai Penerbit Fakultas Kedokteran Universitas Indonesia

Hanafiah, M.Y dan Amir Amri, 1999, Etika Kedokteran dan Hukum Kesehatan, III, Jakarta, Penerbit Buku Kedokteran EGC

Hariyani, S, 2005, Sengketa Medik, Alternatif Penyelesaian Perselisihan Antara Dokter dengan Pasien, I, Jakarta, Diadit Media

Isfandyarie, Anny, 2006., Tanggung Jawab hukum dan Sanksi bagi Dokter, Buku I., Prestasi Pustaka Publiser, Jakarta

dan Fachrizal Affandi, 2006., Tanggung Jawab hukum dan Sanksi bagi Dokter, Buku II., Prestasi Pustaka Publiser, Jakarta

Soejono \& Abdurrahman, 2003, Metode Penelitian Hukum, II, Jakarta, PT. Rineka Cipta

Suwono H., 2006, Perlindungan Hak-Hak Pasien dalam Transaksi Terapeutik, I, Srikandi, Surabaya ---, 2007, Batas Pertanggungjawaban Hukum Malpraktek Dokter dalam Transaksi Terapeutik, I, Srikandi, Surabaya

Undang Undang No. 29 tahun 2004 tentang Praktek Kedokteran

Undang Undang No. 8 tahun 1999 tentang Perlindungan Konsumen 